\title{
The Perception of Women from European Southeast in the Travelogues of the Early Modern Period
}

Divna Mrdeža Antonina (Zadar)

\begin{abstract}
Abstrakt
The subject of analysis in this paper is the perception of woman in several travelogues of European travel writers from the $15^{\text {th }}$ to the early $19^{\text {th }}$ century. In their remarks about the population of the early modern travelogues, during the voyages through the Balkan land and sea routes to the Orient, considerable curiosity for women they encountered, in either public places or in private, was recorded by travel writers. Relatively brief accounts of woman from the first travelogues were extended in the travel writings of the 17th century. Then, they turned into more extensive comments about her position in the community in the 18th century, primarily in the Enlightenment travelogues, some kind of ethnographic record, but also in a kind of adventure reading, as well as in hybrid forms. The focalisation of woman is regularly masculine: the construct of the woman of others is part of the dominant social discourse of the writer's culture.
\end{abstract}

\section{Key words}

the travelogue of the early modern period; perception of woman; the Orient; cultural identity; gender identity

\section{Sažetak}

\section{Percepcija žene s europskog juga u ranonovovjekovnim putopisima}

Predmet analize u članku je predodžba žene u nekoliko putopisa europskih putopisaca od 15 . do početka 19. stoljeća. U opaskama o stanovništvu u putopisima ranoga novovjekovlja, s putovanja balkanskim kopnenim i morskim rutama prema Orijentu, zabilježena je nemala znatiželja putopisaca za žene koje na putu susreću u javnom prostoru i u privatnosti. Relativno kratak opseg opisa žene iz prvih putopisa proširit će se u putopisima u 17. stoljeću. Potom, prerast će u opširnije komentare njezina položaja u zajednici u 18. stoljeću, u prvom redu u prosvjetiteljskim putopisima, svojevrsnim etnografskim zapisima,ali i u vrsti putopisnog avanturističkog štiva, kao i u hibridnim vrstama. Redovito je fokalizacija žene maskulina: konstrukt identiteta žene drugih dio je vladajućeg društvenog diskurza putopiščeve kulture.

\section{Ključne riječi}

putopis u ranom novom vijeku; predodžba žene; Orijent; kulturni identitet; rodni identitet 
Although the factual nature of a travelogue at the time of the early modern period was considered to be the primary feature, its determination as a primarily conventional ${ }^{1}$, marginal genre implies that we today read travel writings as fiction, to a large extent. The travel writers, whose observations are the object of interest in this work, write down the observed during their travels, first and foremost, in the context of the academic culture of the Renaissance ${ }^{2}$, whose theoretical system known as ars apodemica ${ }^{3}$ - the term used by Hilarius Pyrckmair ${ }^{4}$ - became particularly popular exactly in the mid- $16^{\text {th }}$ century and remained rather popular for a long time, until the appearance of the ethnographic record in the 18th century, which is based on description, and the adventurous romantic travelogue, in which the fictional account of events increased its volume. The perception of woman in his own culture, for a masculine travel writer ${ }^{5}$ implies a zero point of view, whereas, in terms of quality, he positions the observed cultures differently on a scale from the lowest tribal-patriarchal ones to the apology of cultures similar to his own. Although domicile, the Western European culture of travel writers profoundly belongs to the patriarchal code. In this context, for the analysis of the discourse ${ }^{6}$ interpretation of patriarchy in different types of texts, the idea of psychoanalysis of the unconscious may be useful. The travel writer as an observer determines the way of how to focalise the observed, and psychoanalysis places the psychoanalytic unconscious in the background of the individual seeing of a foreign woman ${ }^{7}$ and the social norms, which generate "the view, the world and the object", thus producing an illusion tailored to the "desire". The

1 In the Proceedings of De arte peregrinandi libri II, printed in Nurernberg in 1591, the key components are given of the description of unknown countries in the Renaissance travelogue: nomen, figura, capacitas, iurisdictio, situs. In the analysed travelogues remarks are made and data given about the importance, power and safety of the cities and roads, their history and the culture of the population that is encountered.

2 In accordance with the propositions of studia humanitatis, interest in travel offers an opportunity to the members of rei publicae literariae to expand their knowledge about others by observation, not by the transfer of beliefs and rumours (STAGL, Justin: A History of Curiosity: Theory of Travel 1550-1800. Salzburg, 1995, s. 65).

3 Ars apodemica deals with the manner of preparation and equipment of future travellers and advice of how to describe their travels (STAGL, Justin: Op. cit., s. 65).

4 Pyrchmair uses this term in a booklet called Comentar iolus de arte apodemica, seu Vera Peregrinandi ratione, Ingolstadt, 1577 (MILIČIĆ, Irena: Teoretičari, hodočasnici, činovnici: tri vrste renesansnih putopisnih tekstova. Povijesni prilozi 38, 2010, 57).

5 Femina viatrix is articulated as a female cultural and historical voice only in the 19th century, and even then is heard much less than homo viator. For instance, the first women's writing about travel through Dalmatia includes a travelogue preserved in Zadar State Archive by the German authoress Ida von Düringsfeld, who in the mid- $19^{\text {th }}$ century stayed in Dalmatia, published a travelogue (Aus Dalmatien, C. Bellman, Prag, 1857), wrote down folk songs and translated them into German.

6 Discourse understood in accordance to the meanings given to it by Michel Foucault (The Order of Things, The Archaeological Knowledge and The Order of Discourse), with its historical, linguistic and reflective layers of knowledge, in practice, turns into one of the tools of the will for power. In this context, terms such as Morlacchism, Balkanism and Ottomanism are orientalisms and belong to the geopolitical discourse. We can with certain differences (as an example "europeisation" of oriental culture) in the same sense single out Dalmatinism, although it is not explicit in travelogues nor has it become independent in relation to its close descriptive terms in historiographical and cultural literature.

7 If we introduce the explanation of psychoanalysis that woman in patriarchal culture stands as a signifier for the male other (MULVEY, Laura: Vizualno zadovoljstvo i narativni film /Visual and Other Pleasures, 1989, 2, taken from iz Leitch, Vincent B., gen. ed.: The Norton Antology of Theory and Criticism, English trans- 
justification for relying on psychoanalysis when interpreting the discourse in masculine travelogues can be found in the elements of travelogue scopophilia ${ }^{8}$, which is present in the writer's focalisation. Although the travel writer's scopophilia is explicit to a lesser extent than in performing arts, ${ }^{9}$ it is understandable that it is also technically differently mediated by narrative procedures.

Women described in the travelogues were met in public spaces and in passing, since very few travel writers were invited to the private, family sphere, let alone intimate spaces, although they eagerly would talk about this unseen segment. Public spaces in which women could be seen in urban centres are the open spaces of squares/streets as the space of everyday life and social events (festivities are the subject of curiosity of the observer, because of their representativeness for the community), and closed spaces such as the church and the family home. Public space is a showcase of female beauty/ woman's social status ${ }^{10}$ for her corresponding audience (local community) and the place of her presentation to a potential partner and an outside observer. In rural areas, public spaces where women were supposed to be seen included, along with the places of festivities, a rather large number of localities where they carried out different duties. They are often shown in the private family sphere.

In the function of an open showcase as a socially acceptable place for the presentation of woman in the public is certainly the window. It indirectly testifies to the role of woman as an observer of public events, or consequently to the absence of the role of an active social participant (men do not stay at the window!). In the subtext of the impression of the travel writer A. M. Quiclet from 1664, the window is presented as a meeting point of the public and private space, a guaranteed conventional distance (protection) against the contact with an observer - in whose frame the socially acceptable female communication with the outside world takes place. The travel writer glorifies the communication by look with a woman who appears: "[...] made up at the window as they usually do, with her hair adorned with golden ribbons and beautiful decorative necklaces around her neck, with fingers full of gold rings with large roses like diamonds, and also other jewels. Their customs are similar to the fashion in France." ${ }^{11}$ An elusive

lation S. Merić. New York \& London, 2001) in the context of the way of focalising an unknown culture, woman with the eye of the observer of the culture of other is presented to the reader as a two-fold other.

8 Scopophilia implies a pleasure of looking, and its psychoanalytic aspect is presented in Freud's explanation in Three Essays on Sexuality from 1905 (according to MULVEY, Laura: Op. cit., 1989, 3).

9 MULVEY, Laura: Vizualno zadovoljstvo i narativni film /Visual and Other Pleasures, 1989, 3, taken from iz Leitch, Vincent B., gen. ed.: The Norton Antology of Theory and Criticism, English translation S. Merić. New York \& London, 2001.

10 The beauty of woman primarily implied the corporeality in the wider sense (associated with health and fertility). It is also a reflection of the woman's social status, because in the aesthetic standards of many observers, a beautiful appearance is associated with wearing expensive jewellery and clothes.

11 QUICLET, Monsieur: Le voyage de M. Quiclet a Constantinople par terre: enrichis d'annotations, Chez Pierre Promé, 1664. (Fragment). In: MØNNESLAND, Svein: Dalmacija očima stranaca, Dalmatia through foreign eyes. Ed. Tonko Maroević. Zagreb - Oslo: Fidipid - Sypress, 2011, 49. 
beautiful picture stimulates masculine imagination ${ }^{12}$ in the subtext of the described scene, suggests the beauty of the owner of the jewels, but does not describe it. The attitude to female beauty is apologetic due to the jewellery - on the value scale of the observer, it is equivalent to the valuables in his culture. ${ }^{13}$

For the construction of erotic phantasm, the observer borrows the literary function ${ }^{14}$ of the window, first of all from love poetry: a window sill in poetry is the topos of the lover's first look. It is the space of male-female verbal communication (flirtatiousness and gallantry) in a scene noticed during a carnival, when bans slacken: "The carnival is also joyful in other places, there are a lot of disguised people, pleasant and well-dressed, a young man in love at this time will not forget to throw up to his sweetheart, looking from the window, fake wax lemons flled with flowers, small live birds and small balls, also made of wax, filled with pleasantly scented water, as a sign of friendship, and she will receive it all with a lot of grace".$^{15}$ Fascination with luxury seems like borrowing from the reading of a narrator about exotic women and is aimed at stimulating the imagination, longing and envy of the reader for the privileged observer.

Along with the artificial luxury, a companion of female beauty, another important adornment seems to be chastity, which is included by travel writers as a natural value category: "they walk outside, however, with utmost chastity". ${ }^{16}$ The irony in the remark of Foresti da Bergamo about the provocative way of dressing of the women from Kotor also implies the value aspect of chastity, mediated by the writer's fascination with the "undesirable corporeality" of these women. The presentation belongs to the hyperbolised imagery of female nudity: "Their women are obviously not afraid of the cold. They walk with a completely bare chest and shoulders from the breasts upwards and they dress up in such a way

12 Here is another example of the enchantment with valuable things: "Considering the importance of the city, I saw, especially on Sundays, several beautiful women, not many though, but those I saw were really beautiful and richly decorated with jewels. They were dressed in the manner described above and with the shine of gold, silver and pearls. They like being looked at, even by strangers" (DA BERGAMO, Foresti: Supplementum Chronicarum. Venecija: Bernardino Benali, 1483, 32. In: MØNNESLAND, Svein: Dalmacija očima stranaca, Dalmatia through foreign eyes. Ed. Tonko Maroević. Zagreb - Oslo: Fidipid - Sypress, 2011).

13 The permission of wearing jewellery and fur was in contrast with the expected everyday life in the Early Modern Period Dubrovnik. The provisions of the Government at the time of paying the poll-tax to the Ottomans also regulated the way of dressing for people of both genders.

14 In the Renaissance comedy, the window with a view of the street is regularly the setting of the plot, inseparable from the street and the Renaissance square, where the Mediterranean everyday life takes place, so the window becomes a place of conversation and arguments of the female characters, communication with servants, sending messages, making appointments, spying on the neighbours. It is one aspect of the space of woman's public activities in the domain of her everyday life, but here, for us, this is of no interest.

15 QUICLET, Monsieur: Le voyage de M. Quiclet a Constantinople par terre: enrichis d'annotations, Chez Pierre Promé, 1664. (Fragment). In: MØNNESLAND, Svein: Dalmacija očima stranaca, Dalmatia through foreign eyes. Ed. Tonko Maroević. Zagreb - Oslo: Fidipid - Sypress, 2011, 49. Apropos, the described gallant behaviour finds its motif correspondence in Renaissance and Baroque literature, among the motifs of gift exchange between lovers in poetry, such as, for example in the famous poem Ptici svojoj u ruci gospoje (To my bird in the hand of the lady) by Sabo Bobaljević Glušac from Dubrovnik.

16 DA BERGAMO, Foresti: Supplementum Chronicarum. Venecija: Bernardino Benali, 1483, 32. In: MØNNESLAND, Svein: Dalmacija očima stranaca, Dalmatia through foreign eyes. Ed. Tonko Maroević. Zagreb - Oslo: Fidipid - Sypress, 2011. 
that their breasts keep the clothing from falling down on their feet." ${ }^{17}$ A similar perception of female beauty/corporeality was preserved even after the early modern period, up to the $19^{\text {th }}$ century. ${ }^{18}$

In the description of noblewomen of Dubrovnik, but also urban women in general, the inventory of precious items reveals that the delighted observer implies a shared value system of his own and the observed culture. ${ }^{19}$

The observer does not always share the same aesthetic canon with the observed culture and when presenting these urban cultures, women are also qualified as "ugly" or "strange": "Women in Dubrownik look very strange, because they mostly wear strange costumes. I do not know how to describe them, but I can assure you that the costumes are more than decent. Not only do they wear the costumes which cover everything up to the neck but they also have something that looks like a tail of a fattened ram, which goes to the front right under the chin and to the hair at the back." ${ }^{20}$ In a similar way the dress code of Dubrovnik women is described by Nicolas de Nicolay ${ }^{21}$ and A. M. Quiclet: "Local women in our eyes are very badly-dressed, almost like in Genoa, with a big ugly tail, whether they wear skirts or dresses." ${ }^{22}$ At the basis of the statement which finds the fashion of an unknown place repulsive, there is an unre-

\section{Ibidem.}

18 For example, in evaluating the way of dressing of a woman from Kotor, the glorification of chaste corporeality dominates the artificial jewellery: "Women from Kotor are generally characterized by their beauty. There is much more generosity in the posture and facial expression of this countess than in her clothes, which, were it not for some halfcrown placed on her forehead, would be reminiscent of the costume of a maid of the lowest rank" (DE MOLEVILLE, Bertrand: Nošnje nasljednih država vladarske kuće Austrije. London, 1804, 112. In: MØNNESLAND, Svein: Dalmacija očima stranaca, Dalmatia through foreign eyes. Ed. Tonko Maroević. Zagreb - Oslo: Fidipid Sypress, 2011). Moleville's attitude, in fact, mediates the illustrator's view of the undefined female costumes of Kotor and accepts clothes and ornaments as a status symbol. The hierarchy and terminology of the Kotor nobility and women's traditional costumes are rather different from those suggested by the illustrator. Imagination relying on the romantic discourse about the oriental area is discernible in the soft folds of the clothes, which reveals a lot of sensuality in the focalisation of the object of desire, in comparison with the thick folds of the skirt of the elite European fashion of the 19th century. Interesting is the conceptual similarity in emphasising details of Moleville's description from the late 18th century and Grünemberg's description of the bride in a wedding procession from the 15th century: a strangely decorated dress with a diamond crown on her head. It is evident that the early modern period retained an ambivalent view of the area which was called the East; and the Modern Age does not abandon it lightly either.

19 A journey (and indirectly a travelogue) satisfies the elementary curiosity and desire for pleasure in looking, which are mixed with fascination, similarity and re-introjection of an ego-ideal in the observed world. (On introjection of the viewer into the movie hero, comp. MULVEY, Laura: Vizualno zadovoljstvo $i$ narativni film /Visual and Other Pleasures, 1989, 4, taken from iz Leitch, Vincent B., gen. ed.: The Norton Antology of Theory and Criticism, English translation S. Merić. New York \& London, 2001).

20 DA BERGAMO, Foresti: Supplementum Chronicarum. Venecija: Bernardino Benali, 1483, 32. In: MØNNESLAND, Svein: Dalmacija očima stranaca, Dalmatia through foreign eyes. Ed. Tonko Maroević. Zagreb - Oslo: Fidipid - Sypress, 2011.

21 "Their women are not beautiful and wear only local costumes, high head dresses of fine linen, while those more stylish wear those of white silk, and their socks reach the heels" (DE NICOLAY, Nicolas: Les navigations, peregrinations, et voyages faictsen la Turquie, Antwerpen, 1576, 37. In: MØNNESLAND, Svein: Dalmacija očima stranaca, Dalmatia through foreign eyes. Ed. Tonko Maroević. Zagreb - Oslo: Fidipid Sypress, 2011.

22 QUICLET, Monsieur: Le voyage de M. Quiclet a Constantinople par terre: enrichis d'annotations, Chez Pierre Promé, 1664. (Fragment). In: MØNNESLAND, Svein: Dalmacija očima stranaca, Dalmatia through foreign eyes. Ed. Tonko Maroević. Zagreb - Oslo: Fidipid - Sypress, 2011, 49. 
alised expectation of the observer, who accepts only the dress canon of his own culture. It is interesting that in the description of what is not beautiful in terms of fashion, there is no description of the valuable jewellery. The observer's surprise also reveals his complete distancing from the game of male-female attractiveness.

In the public space such as the street, the travel writer's attention is attracted by rituals such as a wedding procession. Details of female ornaments are a distinguished component, and in the description of such an occasion, as shown by Grünemberg's description of a bride from the 15th century (1486): "In Zadar, we saw a wedding procession. The women were wearing all kinds of decorations of ribbon and clothing. The bride had a beautiful golden crown with precious stones on her head, and above it a small wreath. When she came to the end of a street, where another one began, she stopped and bowed to the crowd that were watching the procession. Then, from the nearby houses she was showered with wheat, oats, barley, and all other kinds of grain." ${ }^{23}$

The scene of the colourfulness of women's costumes is made fictional by the precise hyperbolisation of the value of the virginity symbol on the girl's head: "a golden crown with precious stones". Into the experience of the exotic scene, the travel writer also interpolated a mixture of fascination and desire for the fabulous wealth that is often associated with the East.

In the urban culture of Christian South, gender relationships were perceived as strictly patriarchal by travel writers, which in their opinion were not inherent to their own contemporary culture. Women of Dubrovnik, who, to Nicolay, are not beautiful, were closed due to the patriarchal discipline: "Very rarely do they leave the house, but they like peeking through the window to look at passers-by. They also keep their daughters in ${ }^{24}$ so that they would not be looked at." ${ }^{25}$

Rare appearances of women in public gave cause for a witty remark, in which the stereotype was interpolated about women's laziness: "As I heard, they are not really fond of working or earning a living. [...] The Ragusans do not keep wine in the house, and they order it from the inn; even women and servants do it secretly if they want wine." ${ }^{26}$ The topic of laziness and wine idleness reveal the curiosity for the encroachment into the intimate space of woman. If we, however, compare Da Bergamo's comment with the description of the daily activities whose difficulty is pointed out in an erudite comedy and about which female servants talk in an ironic mode, the presentation of the family life of Dubrovnik elite in the home, does not appear to be much different from the life of the social elite in the culture of Western European travel writers. In reality, the scope of activities of

23 VON GRÜNEMBERG: Konrad Hodočasničko putovanje od Konstanza do Jeruzalema, 1486, 20. In: MØNNESLAND, Svein: Dalmacija očima stranaca, Dalmatia through foreign eyes. Ed. Tonko Maroević. Zagreb - Oslo: Fidipid - Sypress, 2011.

24 Foresti da Bergamo met them on Sundays: "they like being looked at, even by strangers; they walk outside, however, with utmost modesty" (Da BERGAMO, Foresti: Op. cit., 1486, 32).

25 DE NICOLAY, Nicolas: Les navigations, peregrinations, et voyages faictsen la Turquie. Antwerpen, 1576, 37. In: MØNNESLAND, Svein: Dalmacija očima stranaca, Dalmatia through foreign eyes. Ed. Tonko Maroević. Zagreb - Oslo: Fidipid - Sypress, 2011. 
noblewomen usually included managing the household and servants, as well as bringing up the children.

According to the remarks made by travel writers, patriarchy did not leave Dubrovnik salons either, and Alexander Sapieha, a Polish nobleman (1773-1812), noticed this in the lack of social skills and salon communication among the female members of the elite: "Neither in their charm nor education are the noblewomen equal to the noblemen ${ }^{27}$ and do not deserve attention of strangers, in contrast to the maids, who are very beautiful." ${ }^{8} \mathrm{Of}$ course, the prince's affinity for the girlish pastoral charm of maids was shown at the time inclined to the glorification of Arcadian grace. Sapieha is not bothered so much by the aversion of noblewomen to strangers, but he feels the need to point out his own affection towards maid servants: "It is their charm that substitutes for the fact that they were not born into a noble family." ${ }^{29}$ His valorisation of "natural grace" is the explicitly expressed tendency to eroticized pastoralism, which was encouraged by the cultural context of the epoch. For example, the popular Anacreon's poetry of the 18th century is particularly pointed out as a cultural taste of the Rococo followers.

Travel writers of the early modern period, in the role of curious observers of other, expressed a greater lack of inclination towards the aesthetic canons of rural than urban culture. In the first place towards the woman's appearance: the type, function and material value of the ornaments worn by the rural female residents in the Christian area in the hinterland of Dalmatian towns and the interior of the Balkans. For example, in the scene of the dance ritual of "lazarice" from Bulgaria, Sura Klisura in 1576, Marco Antonio Pigafetta is a superior observer: the female costumes are strange and repulsive, and their dancing and singing are wild, though the girls are beautiful. He is not alone in this model of presentation. A similar description of the costumes from Pirot, as well as the songs and pair dancing from Suha Klisura is also given by Jakob Betzek, Pierre Lescalopier and Antun Vrančić. ${ }^{30}$ Pigafetta evaluates the way of dressing, singing and dancing

27 Sapieha largely draws on Fortis's Enlightenment travelogue. However, he shares Fortis's approval of Morlacchi's attitude to women more than his evaluation of urban culture. Fortis was more inclined to the urban centres which accepted the influence of Venetian culture. The Slavic patriarchal model of Dubrovnik was, according to travel writers, associated with Ottoman culture, since they regularly emphasise that oriental culture also jealously guards women from the male look. History of literature also records distrust and dislike of social involvement of women in the early modern period. For example, to the educated sisters Julija and Nada Brnić, Mare Gundulić and Cvijeta Zuzorić, some of the rare educated women and poets.

28 SAPIEHA, Aleksander: Podróže w krajach stowiańskich odbywane. Wrocław, 1811, 119. In: MØNNESLAND, Svein: Dalmacija očima stranaca, Dalmatia through foreign eyes. Ed. Tonko Maroević. Zagreb - Oslo: Fidipid - Sypress, 2011.

29 Ibidem.

30 It is a custom in which "lazarice" from the master, for whom they sing, receive a reward: eggs, wool, flour. They do not dance for money, as Pigafetta believes. Although the discourse of the superior observer in describing rural cultures in the territory of the European Turkey and the hinterland of the Dalmatian coast can be found in the first travelogues of the early modern period, as a discourse of Morlachism it 
as savage in comparison to the luxurious parades in Istanbul, while his companion Antun Vrančić considers the perceptive, not the real value of those ornaments: "One woman asked me if our women were adorned so beautifully. Lucky them when they do not know about our luxury, and see their own in things of no value! And they are satisfied with their poverty in the same way our women are with their wealth!"31 Vrančić is the primate of Hungary, a West European, like Pigafetta, but recognises the value of jewellery as arranged, not its "real" value. An understandable attitude for a Church prelate. We can speculate about whether his opinion included an attitude about similarity rather than difference. He considered himself a Croat from Šibenik and that Bulgarians spoke the Croatian language, so the customs of the Slavic ethos did not represent the exotic of other.

Travel writers identify themselves as apologists of their own culture (admirers of the contemporary West European fashion sense) when they record their impression of exotic female costumes. Alberto Fortis, for example, explicitly defines the origin of such an attitude: "the attire of Morlach women [....] in the Italian eye is always equally strange". ${ }^{32}$ And when an observer allows himself a "generous" assessment: "and it must be admitted that in the variety of these wanton and barbaric ornaments, a kind of spirit can sometimes be seen", ${ }^{33}$ with these qualifiers, he clearly distances himself from the observed culture in accordance with the perception of his own position on the hierarchical scale of cultures.

In travelogues, where the observation of gender relations in the rural culture of the European south is one of the topics of ethnographic interest, descriptions of women are regularly connected with comments on their position in the community. The basis of Fortis's Morlachism ${ }^{34}$, the myth of a pre-civilised barbarian of the newly-discovered

will appear only after Fortis's ethnological record about the economically underdeveloped parts of the Balkans. It became a dominant discourse of the description of primitive peoples in literature and culture in the Europe of the $18^{\text {th }}$ century, with its echoes felt well into the $20^{\text {th }}$ century.

31 VRANČIĆ, Antun: Putovanje iz Budima u Drinopolje. In: FORTIS, Alberto: Put po Dalmaciji. Prep. Josip Bratulić, translated from Latin by Darko Novaković. Split: Marjan tisak, 2004, 134.

32 FORTIS, Alberto: Put po Dalmaciji. Pep. Josip Bratulić, translated from Italian by Mate Maras, and Latin Darko Novaković. Split: Marjan tisak, 2004, 46.

33 Ibidem.

34 By its ubiquity and power of influence, Fortis's Morlachism is comparable to Orientalism. For example, as a very early echo of Fortis's travelogue, there is a well-known novel Les Morlaques by the writer Justine Wynne, countess Contessa Orsini-Rosenberg from 1788. Although it is generally considered that the myth about the good savage appeared with the first descriptions of primitive civilisations in the newlydiscovered America (COCHIARA, Giuseppe: Istorija folklora u Evropi 1 (Storia del folklore in Europa). From Italian by Tatjana Majstorović and Julijana Vučo. Beograd: Prosveta, 1984, 21), we find it earlier as part of the discourse of pastoral literature and the mythic, golden age of Greece and Rome. The idea of an unspoiled world and man was introduced in the early modern period by Boccaccio's Ninfaled'Ameto, and was extended in the leading European literature under the influence of Sanazzaro's Arcadia. With the discovery of the exotic area of the East, in particular the discovery of America, it also became a discourse of geopolitical pretensions. As a philosophical idea about the world of unspoiled civilisation, based on reason and the parallel world of spoiled civilisation, it was popularised by Jean Jacques Rousseau in the $18^{\text {th }}$ century. The rural patriarchal man/woman (the Morlachs) is a pattern for the construction of a model 
world, ${ }^{35}$ the mythical complex of Morlachs, predictably implies a poor active participation of women in the public life of the community.

In the referential context of Fortis's construction of Morlachism, there is an explicit emphasis on the pastoral concept ${ }^{36}$ of life, in which the perception of the woman's role also has a place: "The innocence and natural freedom of shepherds' centuries have still been maintained among the Morlachs or at least many traces have remained in the places which are far from our villages. The pure cordiality of feelings is not hindered by considerations here, and is clearly expressed with some external signs, regardless the circumstances. ${ }^{37}$ Members of the same group quite intimately treat each other, with a lot of tactile expressions of cordiality, when meeting members of their own people, which would be considered to be erotic in Fortis's culture: "A beautiful Morlach girl, who meets a man of her district, on the road, kisses him affectionately without the least immodest thought." 38

A layer of the pastorally attractive has a different layer of meaning as well. The travel writer equates the forms of social coercion with the signs of pastoral harmony and cordiality: "In the surroundings of Drniš, in their first year of marriage, brides have to kiss all the men they know when they come to their house, but after the first year they are released from such courteousness." ${ }^{39}$ The obligation of welcoming a male guest with a kiss is a form of coercion, which ends up when a woman "becomes unworthy" of that role: "I had the opportunity to see that almost everywhere that contempt for the female gender prevailed and rightly so, because it is not at all graceful nor gentle, but rather it distorts and spoils the gifts of nature." The attitude of the writer is brutally misogynist. A woman's value is measured on the scale of pleasure for man: the loss of grace is the cause of contempt for women and not the result of social coercion on (self)neglected women. To what extent this evaluation model affected later ${ }^{40}$ travel writers is evidenced by an almost literal repetition of Balthasar Hacquet from 1801 about the state of neglect of women from Pelješac. It seems

which, in the $18^{\text {th }}$ century would be popularised by Voltaire's Essay on Customs (1754), in which the rural culture in the hinterland of the Adriatic is characterised as pre-civilisation based on instinct, like the communities of Islanders, Lapps and the Hottentots (BEŠKER, Inoslav: Morlakizam i morlaštvo u književnosti. Književna smotra: časopis za svjetsku književnost 34, 123 /2002/, 1, 114).

BEŠKER, Inoslav: Op. cit., 120.

36 Fortis's presentation of the Morlachs at the functional level is determined by the tasks set out in the preface to John Stuart, Earl of Bute (1713-1792), an advocate and propagator of Macpherson, or his mystification of "Ossian" epic Fingal: "Staying with us, you must have heard more than once talking about the Morlachs as being a savage, unreasonable ilk, devoid of humanity and capable of any atrocity [...] but these deeds [...] their character should be attributed to the corruption of a small number of individuals rather than to the generally bad temper of the people" (FORTIS, Alberto: Op. cit., 33). The travel writer constructs the perception of a "fossilised" artefact of a living community that bears witness to a mythical-poetic origin of Europeans in an imaginary Fingal. Urged by the gratitude for the hospitality: "I think I owe to the people who received me very well and treated me humanely an extensive apology..." (FORTIS, Alberto: Op. cit., 33). Indirectly, the apology of the primitive community: brightness and artefact of the Morlachs, their artistic skills, hospitality and savagery, tendency of art should help the Earl in his battle for the "Ossian" authorship.

FORTIS, Alberto: Op. cit., 92.

38 Ibidem.

39 Ibidem, 94.

40 Numerous coincidences in the descriptions of the predecessors and their followers point to the use of the established stereotypes and general places, as it is regularly present in the descriptions of primitive 
that Fortis's travelogue was also copied by Hacquet's contemporary Schoberl 1821, in a similar description of the behaviour and appearance of young men and women. ${ }^{41}$

In addition, Fortis's comments on the code of female cleanliness in a primitive rural community reflect less concern for the culture of hygiene, and much more adherence to the "impure aspect of the feminine", the cultural and religious stereotype which dominated Western Christian culture. ${ }^{42}$ Man is excluded from the "culture of physical aversion", although the writer's view of the economic and cultural reality of Morlachia provides enough material for an identical judgement of both genders.

The cultural context renders understandable the system in which it is indirectly implied that the ornament is inappropriate for the marital status of woman. Therefore, the state of neglect is a kind of status "ornatus" of a married woman, who must not be attractive to others. And along with the girl's real purity, the category of affirmative ornament also includes the symbolic purity: "An unmarried woman, who falls under the imputation of want of chastity, runs the risk of having her red cap turned off publicly in church, by the curate and her hair cut by some relation in token of infamy." Taking away the "girl's" features in public is also an act of violence.

The travel writer also dedicates a lot of space to the submission of woman by battering, which is a coerced "tactility" he comments with a hint of humour, which reveals an affirmative attitude to such practice. The masculine interpretation of the Stockholm syndrome barely conceals his contempt for the female sex: "And it seems in general, that the Morlach women, and perhaps the greatest part of the Dalmatians, the inhabitants of the cities excepted, do not dislike a beating now and then, either from their husbands, or lovers." ${ }^{3}$

cultures. Tidy- untidy is only one of many binary oppositions through which a primitive culture is commeasurable with Western culture.

41 Hacquet links the grace of women with youth and new clothes, which, when worn out, become dirty (HACQUET, Balthasar: Oslikavanje i opisivanje jugozapadnih i istočnih Wenda, Ilira i Slavena. Split: Ethnographical Museum of Split, 2008, 114).

42 The negative aspect of women's corporeality/impure sin was increasingly offered from the Middle Ages. For example, a Croatian misogynist poem Ot ljubavi ženske (On women’s love) from Tkon collection, educates readers, especially young clerics, stirring up the male fear of women stereotypically imagined in the role of Eden destroyers and the incarnation of the sin of a vampire-like women's lust.

43 FORTIS, Alberto: Op. cit., 94. Corporal punishment is a ritual transfer of a daughter to her future master/husband.: "they start listing her bad characteristics! Well now that you will have her, you should know that she ill-natured, defiant, obstinate, etc. On which the bridegroom, affecting an angry look, turns to the young woman with an: "Ah, since it is so, I will teach you better manners ". With these words he slaps her in the face, or kicks or punches her, or treats her with some other kind of courtesy..." (FORTIS, Alberto: Op. cit., 52). The signs of submission/ obedience to the community are recorded in passing, in some other ceremonials as well. For example, in the ritual of a wedding feast, which marks the symbolics of serving the new family/master: "she kneels down and kisses the threshold" (FORTIS, Alberto: Op. cit., 50). Submission is publicly glorified, for example, by degrading the bride immediately after the consumption of her wedding night because of the lost status of a virgin: "The next day the bride, without her veil and virginal cap, bare-headed dines at wedding table and is forced to listen to the coarse equivocal jests of intoxicated guests..." (FORTIS, Alberto: Op. cit., 51). 
The described gender relationships are beyond social segregation. Women, regardless of their class/material status, were forced to dress modestly: "Girls, even from the wealthiest families, were not allowed to wear different shoes. When they got married, they could refuse to wear (opanak) the Balkan peasant shoes and wear the Turkish slippers if they wanted." ${ }^{\prime 4}$ Stigmatisation of opanak opens and widens the semantic circle of the relationship to the group governed by the rules relevant for gender, and not a social class. The stigma of the mortal sin of hubris in the "female" version, manifested in the tendency to dress luxuriously, is generally intensified by the Western culture of the Christian Middle Ages ${ }^{45}$.

The writer's comment on the fragility of the class/material status of Morlach women reveals that the position gained by birth was guaranteed to the woman only during her girlhood, since a suitable class-marriage was not established as a norm for the daughters of a wealthy peasant: "It often happens that a wealthy Morlach gives one of his daughters to his own servant or serf, as it was done at the time of patriarchy, so little are women valued in these parts. ${ }^{46}$ Woman is the property given as a present to the loyal subordinates. Fortis's interpretation of the patriarchal feudal transfer of women is reminiscent of gender value in the oral narrative forms, especially in epic poetry or fairy tales, in which we find similar solutions to the matrimonialisation of the hero: a poor young man who has proved his loyalty to the monarch marries the king's daughter. ${ }^{47}$

The attitude about women as lower beings is also present in the interpretation of the European discussion on the gender of the hermaphrodite Michelle Anne Drouart, which was of topical interest in Fortis's time. It was associatively prompted by an incidental encounter with a hermaphrodite foal, a strange creature, ${ }^{48}$ seen in Zadar. Fortis considers the French medical and ecclesiastical ruling that the hermaphrodite is of male gender as a cultural scandal. "The Archbishop's office forced her by issuing a special order to wear male

44 FORTIS, Alberto: Op. cit., 92.

45 This is evidenced by a medieval Legendarium about women saints. Features such as modesty, humility, obedience, chastity are usually glorified as virtues, and the most common vice is hubris (excessive pride). In the context of an appropriate code of conduct "hubris" was also thematised in the $18^{\text {th }}$ century, and it implied a tendency to luxurious beautifying and dressing. Comp., for example, the literary theme of hubris as a repentance for sins In: KANIŽLIĆ, Antun: Sveta Rožalija Panormitanska divica nakićena i ispivana po Antunu Kanižliću Požežaninu. Wien, 1780.

46 FORTIS, Alberto: Op. cit., 48.

47 The concept of social (class) transfers has also been known through history in the cultures in contact. For example, it was characteristic of the Ottomans: The Sultan would marry his sister's sultanias to high court officials, who at the time of the rise of the Empire were often slaves.

48 An encounter with monsters and fantasy creatures, unbelievable events is a commonplace in travelogues about exotic countries. They are invariably contained in travelogues (and novels of chivalry), and are also quite common in the travelogues of the early modern period. For example, Ludwig von Rauter in 1569 related the story about a miraculous s resurrection of a hanged bandit, which happened in the Church of St Simeon in Zadar, where the saint's remains are kept (VON RAUTER, Ludwig in: MØNNESLAND, Svein: Dalmacija očima stranaca, Dalmatia through foreign eyes. Ed. Tonko Maroević. Zagreb - Oslo: Fidipid - Sypress, 2011, 35); William Lithgow in 1614 told the story about a strange freak creature that was born on the island of Hvar, during his stay there (LITHGOWN, 1614. Ibidem, 46); Giovanni Batista Rostagno in 1668 recorded the "verity" of a sea monster which took a human victim every year (ROSTAGNO, 1668. Ibidem, 56). 
clothes." 49 "The scandalous" behaviour of the "woman" is a "more scientific" argument than the medical evidence on gender of the French Academy: "in 1769 in Venice, she showed [herself] for money to the curious onlookers and professors". He is an advocate of professor Caldini of Padua, who "declared the hermaphrodite a monstrous and hideous female". By identifying himself as an educator, interpreter-anthropographer who describes, analyses and evaluates, among other things, also relationships between genders, Fortis is trying to manipulate the reader.

Even when he expresses sympathy for the woman from the rural patriarchal culture in Dalmatia, Fortis's discourse is masculine and westerly hegemonic. Also, it is a European projection of the perception of their own mythical great-parent, the Amazon preserved in the body of a Morlach woman. In this respect, particularly interesting is the mythicalpoetic apology of the mother parent and her Spartan physical endurance (giving birth in the field and bathing the newborn in cold water $)^{50}$, which advocates the idea of submission to the Spartan hero. The mythical-poetic aspect of her strength also includes an armed self-defence of virginity. ${ }^{51}$ The concept of the virgin warrior ${ }^{52}$ does not, naturally, correspond with the cultural and historical reality, because ethnological and historiographical studies invariably bear witness to women being coerced into marriage. The Spartan endurance of a child-bearing woman is not in correlation with anthropological data on the incidence in maternal and infant mortality in rural areas.

The perception of woman as an intuitive being as opposed to the hero figure is also of a mythical-epic origin. She has the role of the "protector of the hearth" in the rural patriarchal culture, expressed in the subtext of Enlightenment criticism of the "protector of memorabilia". ${ }^{53}$ The view of the "protector of a collective memory of the dead"- of a grieving mourner, who follows the deceased from the house to the cemetery with

49 FORTIS, Alberto: Op. cit., 14.

50 "A Morlach woman neither changes her food nor does she stop hard labour because she is pregnant; and is frequently delivered in the fields or on the road by herself, she takes the infant and washes it in the first water she finds, carries it home and returns the day after to her usual labour, or to feed her flocks." (FORTIS, Alberto: Op. cit., 52).

51 "It rarely (and it certainly does not happen in places far away from the fair) happens that a Morlach carries off a girl against her will or dishonours her. And were such attempts made, the young woman would no doubt be able to defend herself, because the woman in that country is generally very little less robust than the male." (FORTIS, Alberto: Op. cit., 46).

52 The image of an armed Amazon has long been reproduced as a construct of Morlachism. For example, Balthasar Hacquet wrote, like Fortis, in a travelogue from the early 18th century (1801): "in the mountains, a woman is rarely found without a dagger or a knife around her waist so that she could defend herself against attacks of any kind" (HACQUET, Balthasar: Oslikavanje i opisivanje jugozapadnih i istočnih Wenda, Ilira $i$ Slavena. Split: Ethnographical Museum of Split, 2008, 114).

53 Fortis criticises the nurturer of the male vows for revenge. Hostilities "are passed from father to son; and mothers do not fail to remind their small boys about the obligation ahead of them to revenge their parent, if by accident he was killed, and they often show them the bloody shirt or weapon of the deceased" (FORTIS, Alberto: Op. cit., 61). It is, of course about the role of woman in the forming of the patriarchal unconscious. She brings up her child in the dimension of the language, law and father (Lacan's symbolic): „her significance in the process, once this has been achieved, comes to an end" (MULVEY, Laura: Op. cit., 1989, 1). 
laments of epic content and dimensions and regularly visits the dead as a messenger between the two worlds asking them about the news from the other world and bringing them the news from this world. ${ }^{54}$

Perceptions of the incarnations of the mythical virgin warrior and protector of the hearth, as well as the interlocutor with the world beyond implicate the tendencies of the observer arising from the misogynistic presentation of women. Sympathy and misogyny meet in the men's fear of women's power, and the fear is recognisable in a bizarre example of Morlach superstition, which the travel writer mocks: a Franciscan friar resurrected a young man, to whom the witches (a girl and an old woman) stole the heart and baked it with the intention to eat it..$^{55}$

At the time when Fortis recorded this superstitious little story, the dominant cultural horizon was formed by the ideology of post-Tridentism, which, in the field of amorous relationships, advocated the view of pernicious women's love. ${ }^{56}$ The ideas were interpolated in various forms of popular culture, primarily urban, and were also successfully deposited in the rural patriarchal community. Their literary attire was an echo of the amorous discourse in the literature of the early modern period, in whose phraseology the lover has a burning, flaming, glowing heart, or is, for example, heartless. In an oral example, the metaphorical thief of hearts from literature ${ }^{57}$ became literally an eater of men's hearts. ${ }^{58}$ Love acquires the dimension of a comic-grotesque ill-fate, and the heart by losing its metaphorical meanings becomes real food. A metaphor realised in such a way also implies a transformation of the "callous sweetheart" into a "real witch. ${ }^{59}$ The

54 FORTIS, Alberto: Op. cit., 61.

55 "I know a young man, whose heart was ripped out in his sleep by two witches, who wanted to bake and eat it. The poor boy did not notice it, which is quite natural, because he was asleep; but when he woke up he began to complain, feeling an empty place where his heart should be "The witness to this fantastic event with the witches, at the same time dues ex machinae, was a friar: "The friar approaches the hearth, takes the baked heart from the live coals and gives it to the young man who eats it; quite understandably, he was cured as soon as he swallowed it. The reverend used to retell this time and again, and he may still be telling it, swearing by his soul that all of it is true" (FORTIS, Laura: Op. cit., 44).

56 At the time of Catholic restoration, the church by means of an increased internal control of clergy strengthened the practice of weakened celibacy, and in art and literature, it spread a negative view of eroticism pleading for the themes of appropriate love. Thus in the centuries when the ideas of the Trident Council were intensively nurtured, the conjuncture of misogynist themes and views in Croatian literature was increased and such were the attacks on women in "Cvitju šestom" in Kita cvitja razlikova by Ivan Ivanišević, the sinner in Baroque religious poems or in the criticisms of eroticism of the negative female characters in Dubrovnik librettist dramas.

57 The literary aspect of the women thieves of hearts is part of amorous relationships which was dominant in the pastoral literature of the early modern period after Sanazzaro's Arcadia, which was also introduced in the context of Croatian pastoral literature from the poet Zoran in the The Mountains to many other lovers who had to go through the process of magic for the purpose of the absolution of their heart from love pain.

58 In the related "event", the travel writer derisively cuts off the superstitious layer of the interpretation of reality by introducing a realistic eroticised background: "good people did not think, nor do they think now that it is allowed to suspect that he was imagining, because of wine, that these two women, one of whom was old, flew away for an entirely different reason, and not because they were witches" (FORTIS, Alberto: Op. cit., 45).

59 The transfer of divinisation into demonization is also expressed in written literature. In the Baroque comic poem, for example, the Dervish by Stjepo Đurđević, an atypical suitor, such as Dedo the Dervish, 
masculine interpretation reveals a misogynistic attitude towards woman, which is caused by the fear of her power. Male fear is also the trigger point for the punishment in the previously-mentioned virgin's deprivation of her ornaments - she is both symbolically and „really” deprived of her power.

Fear and desire are also the components of the talking about sexuality as animalistic. Fortis provides the modern reader, who in his own culture has not read about sexuality in conventional terms, with a talk about sexuality under the guise of an observer of the culture of the wild. He selects the already seen or imagined scenes and spaces. He, for example presents the sleeping space of the Morlachs as an animal accommodation: "I've been there several times to see them babbling till past midnight, screaming certain diabolic songs, in the same place where I was laid to sleep, and where ten to twelve others were stretched on the ground, fast asleep, notwithstanding their frightful vociferation." 60 "Those very few who have a bedstead, where they sleep on straw, do not stand a woman in it, who has to sleep on the floor and obey only when she is called." ${ }^{1} 1$ The veiled voyeurism of the observer includes similar hyperbolism, like, for example, in the descriptions of dances, which were a regular topics of travelogues: "The circle changes its form, sometimes into an ellipsis, and sometimes a square, according as the dance becomes more animated, and, at last, transforms itself into the most violent springs and leaps, in which women also join, and the whole becomes wild confusion. The Morlachs have an incredible transport for this rude dance." ${ }^{2}$

Misogynistic tones are also spread when a woman from elite culture is compared with a Morlach woman. They are obvious, for example, in favouring the elegant looks and good taste of Venetian women. Although the praise of fashion taste is primarily an apology of Western culture, the Venetian woman is rebuked and sneered at for her „female hypersensitivity“ and physical weakness, as well as the need for men's emotional support, as opposed to the perception of the Morlach woman who is strong and emotionally undemanding. Emotional fragility implicated to women is something that irritates men. They prefer a male-female relationship which does not require engagement.

Women from the Christian area of the eastern Adriatic offer to the western masculine view material for the construction of the stereotype of ideal woman. She is shown by Joseph de Lavallée in the figure of a woman from Split, who is distinguished by her elegance, beauty, communication, tendency toward a rich social life, and at the same time "they are good mothers, reliable friends and faithful fiancées". ${ }^{63}$ The construct of a de-

after an unsuccessful wooing of a girl, complains of sorceries she used to bewitch him and threatens the procedures that he intends to undertake against her for witchcraft.

60 FORTIS, Alberto: Op. cit., 54-55.

61 Ibidem, 52.

62 Ibidem, 59-60.

63 DE LAVALÉE, Joseph: Voyage Pittoresque et Historique de L'Istrie et Dalmatie. Pariz, 1802, 111. In: MØNNESLAND, Svein: Dalmacija očima stranaca, Dalmatia through foreign eyes. Ed. Tonko Maroević. Zagreb - Oslo: Fidipid - Sypress, 2011. 
sired ideal entails a superstructure of the Western Christian culture, which the woman from the eastern Adriatic, in the descriptions of travel writers, usually lacks, and at the same time retains the characteristics of the early stages of patriarchy ("virgin warrior and the protector of the home hearth"). The conceived ideal is in accordance with Fortis's desire. It involves gracefulness of a Venetian woman and the patriarchality of a Morlach. This is obviously what is looked for nostalgically by men inclined to the conceptual hybrid in Lavallée's home culture.

In the area of the southeast of Europe, travel writers also describe encounters with women from the social and cultural context of their own community. They express different emotions and thoughts from those previously expressed. For example, Marco Antonio Pigafetta encounters a column of slaves on the road to Adrianople, in which he notices that women are entirely shielded against the sun so that they may preserve their beauty and the price ${ }^{64}$, and he also sees them in a different situation: as slaves exposed for sale at a fair in Hadrianopolis. The writer is shocked by the buyer's right to a physical contact, whereby he checks the teeth and the health condition of the body of all, elderly women, mothers with children and virgins, who "with their beauty and healthy bodies must be at the buyer's disposal." In the "privileged" look at the exposed woman and a free touch of other - the villain (enemy) - the travel writer's curious look at the exposed/forbidden also participates. The complex interaction of different looks also implies a partial identification of the writer's focalisation with the active observer. The scene is a result of the voyeuristic and scopophilic look of the observer of the scene. The demonstration of the women slaves' health and the free testing (touching) of the body, which by being looked at and touched loses the acquired civilized integrity and self-esteem, urged the observer to react. The gesture of other which annihilates (makes it animalistic) Western culture is indirectly in the service of Pigafetta's fuelling a feeling of fear in the Christian world because of the threat of degradation of his own culture, as well as pointing to the need for showing concern for others.

The sintagmas of "an unfortunate mother with little children in her arms" or "illfate born lasses who have not known a man yet" come from the dominant discourse of maternity and girlhood in the Christian system of values. The iconographic motif mother and child evokes all kinds of reader's associations connected with the values of the renewal of life and suggests emotional pain because they are threatened and need to be protected. Protection was naturally expected from the male, and this is not only a scene viewed by a male eye, but also an appeal to the Christian world of the 16th century for action against the Ottomans. The sintagma "ill-fate born lasses" contains all kinds of associations related to the literary and generally aesthetic layers of the endangered $V e$ nus Coelestis. The endangered Venus and Mother with Child are two representatives of

64 Similar scenes are also contained in other travelogues about the Orient, and Pigafetta's description is almost identical to Vrančić's. 
a shaken male self-esteem in the patriarchally regulated world, and the male fight over the figure of woman for the ownership of her body and through it the re-establishment of his ownership over space.

The degradation of the feminine to the level of goods is not problematized at all at the broader level of Renaissance geopolitics, for example, in a principally similar context of the early modern period, intercontinental slave trade and the conquest of the New World. But Pigafetta's reader does not expect such a thing from their travel writer. ${ }^{65}$ In fact, the sad scene is part of the context of informing them about the diversity and exotics of Bezestan "places in which different types of goods are sold" and "where there are many shops" ${ }^{66}$

The perception of women from the Orient of the travel writer Marco Antinio Pigafetta demonstrates that a common way of adopting the culture of the Ottoman Other led through viewing women from The Ottoman culture. Women from the upper class were primarily the subject of one chapter of Itinerario di Marc Antonio Pigafetta, in which the travel writer explains the meaning of the titular terms of the Empire and their position, especially the dignitaries who were close to the Sultan. The chapter begins with a remark that the Sultan marries pashas, his highest officials- who were invariably former slaves of Christian origin - to the women from his own family. The unusual social position and political role of these noblewomen married to slaves is not a special subject of interest of the travel writer, which is evidenced by the absence of an expected political comment.

More space is occupied by the writer's imagination, in which he constructs for his reader an illusion of the exotic wealth of Levantine culture describing the appearance of the noble Turkish woman: "They are very strictly protected (I am talking about those who are in their homes and not in the Sultan's court), and are constantly guarded by eunuchs, and may rarely or never be seen because when they are in a coach, all the doors are veiled during the ride, and if they are on horseback, they are covered with a black veil, so that only their eyes can be seen, and the rest of their head is covered with a white scarf. ${ }^{" 67}$ He additionally points out their inaccessibility: "They never go on foot or on horseback, but always ride in a coach if they are not in the countryside, but others walk and ride a horse holding their legs like men. They paint their nails, hands and feet with henna, which they also use to paint their mares, and they do it to make themselves more beautiful". Although to the eye of a stranger, especially Christians in diplomatic missions, women were almost invisible, the reader encounters a handful of well-known stereotypes of fictional scenes ${ }^{68}$ which he certainly did not see: "They wear slippers or shoes that are completely covered with gold and precious stones. They sleep

65 Today's reader, in the subtext of the above-mentioned description, reads the Ottoman discourse. Namely, the trade in Christians in the Ottoman Empire was conducted at the same time as the trade in black slaves in the so-called New World.

66 PIGAFETTA, Marco Antonio: Itinerario di Marc' Antonio Pigafetta gentil' huomo vicentino, Londra, apresso Wolfio Inghlese, 1585. In: MATKOVIĆ, Petar: Putopis Marka Antuna Pigafette u Carigrad od god. 1567. Starine, JAZU, 12, 1890, 106-107.

67 Ibidem, 148.

68 It is known, for example, that orientalist painters (mostly romanticist) none of whom ever travelled to the 
in soft sable fur, and wear soft veiled shirts in different colours made of gold and silk, and other clothes beautiful and sumptuous. So much about the local women." ${ }^{69}$ An explicit talk about the female body, imagined as wrapped in veils, sprawling in the softness and luxury is a projection of a hidden observer's desire, the talk of the desire of Renaissance nobility. And since it goes beyond the conventional taboos related to the local women and sexuality in general, as a socially acceptable talk about the "forbidden", it was a voice appealing to a wide reading public, although the descriptions were invariably the generalisation rather than presentation of concrete women.

The travel writer controls the desire of the Renaissance reader by limiting the story about women to some twenty lines of the description in accordance with the rule of ars apodemica, which advises to dedicate more space to the "more serious themes", such as the description of the geographical area, natural resources, economy, military organisation of the country, not to women. In addition, the final wording "so much about these women" attests that the East is presented not only from the perspective of cultural and economic superiority, but also masculine.

The Renaissance curiosity about Istanbul was intensified in Pigafetta's time and the presentation of woman as a longing for the space of luxury which had to be restored / conquered had only just begun.

Travel writers who take the Balkan routes (land or sea) to travel to the Orient, gave increased attention to their descriptions of women's (un)attractiveness and corporeality and the relationship of men and the community toward them. In the brief remarks of travel writers of the 16th and 17th century (such as Foresti da Bergamo, Nicolas de Nicolay, Antun Vrančić, Marco Antonio Pigafetta, Henry Blount) about the population of Dalmatian cities, as well as in ethnographic records of the 18th century (such as the travelogues of Alberto Fortis), the travel writer's discourse reveals a dominant masculine focaliser, positioned under the flag of his own culture.

The construct of figure of the woman of other is an incentive for the travel writer to talk freely about corporeality, which is not allowed in the codified talk about women in his own culture. Travel writers- observers create acceptable modalities of talk about what otherwise "cannot" be talked about in civilised circles of the Renaissance Western Europe. In addition to being the subject of fantasy and desire woman is also the way of adoption of the Ottoman other, which also includes to them unknown area of the eastern Adriatic as well. Female beauty is regularly evaluated positively if women are presented surrounded by valuable objects, jewellery and expensive clothes and they belong to higher social classes, regardless of whether they are the Christian inhabitants of the Dalmatian cities or Ottoman Istanbul. Accordingly, when the imperfections of woman's ornaments are pointed out that often implies her physical unattractiveness.

East, but saw the illustration in travelogues, the favourite themes were scenes from women's baths and harems, Although, they could not have seen such spaces anyway, even if they had travelled to Turkey. 
Rural culture is re-semanticised in travelogues of the 18th century (Alberto Fortis, Joseph de Lavalée, Alexander Sapieha) as a pre-civilised culture of savages, while urban culture is interpreted in a historical rather than mythical key as a hybrid of the Christian and Islamic patriarchy and as a kind of primitive historic stage of Western civilisation. The privileged position of the evaluator allows the travel writer to show his disgust at the primitivism and the apology reflects the need to take control over the "noble savage."

\section{Literature}

BEŠKER, Inoslav: Morlakizam i morlaštvo u književnosti. Književna smotra: časopis za svjetsku književnost, 34, 123 (2002), 1, 113-124.

BHABHA, Homi: The Location of Culture. London - New York: Routledge, 1994.

BLOUNT, Henry: A Voyage into the Levant. Theatrum Orbis Terrarum London, 1636. In: PARKER, Kenneth: Early Modren Tales of Orient: A Critical Anthology. London - New York: Routledge, 1999.

BRATULIĆ, Josip: Prefice to: FORTIS, Alberto: Put po Dalmaciji. Prep. by Josip Bratulić, translated from Italian by Mate Maras, from Latin by Darko Novaković. Split: Marjan tisak, 2004.

COCHIARA, Giuseppe: Istorija folklora u Evropi 1 (Storia del folklore in Europa). From Italian by Tatjana Majstorović and Julijana Vučo, Beograd, Prosveta, 1984.

DA BERGAMO, Foresti: Supplementum Chronicarum. Venecija: Bernardino Benali, 1483. In: MØNNESLAND, Svein: Dalmacija očima stranaca, Dalmatia through foreign eyes. Ed. Tonko Maroević. Zagreb - Oslo: Fidipid - Sypress, 2011.

DE LAVALÉE, Joseph: Voyage Pittoresque et Historique de L'Istrie et Dalmatie. Pariz, 1802. In: MØNNESLAND, Svein: Dalmacija očima stranaca, Dalmatia through foreign eyes. Ed. Tonko Maroević. Zagreb - Oslo: Fidipid - Sypress, 2011.

DE MOLEVILLE, Bertrand: Nošnje nasljednih država vladarske kuće Austrije. London, 1804. In: MØNNESLAND, Svein: Dalmacija očima stranaca, Dalmatia through foreign eyes. Ed. Tonko Maroević. Zagreb - Oslo: Fidipid - Sypress, 2011.

DE NICOLAY, Nicolas: Les navigations, peregrinations, et voyages faicts en la Turquie, Antwerpen, 1576. (http://gallica.bnf.fr/ark:/12148/bpt6k853119/f7.)

DE NICOLAY, Nicolas: Les navigations, peregrinations, et voyages faictsen la Turquie, Antwerpen, 1576. In: MØNNESLAND, Svein: Dalmacija očima stranaca, Dalmatia through foreign eyes. Ed. Tonko Maroević. Zagreb - Oslo: Fidipid - Sypress, 2011.

DUDA, Dean: Književno-povijesna retorika putopisa. Kolo, 8, 1998, 1, 263-302.

DUDA, Dean: Hrvatski romantičarski putopis kao pripovjedni žanr. Zagreb: Matica hrvatska, 1998.

FORTIS, Alberto: Put po Dalmaciji. Pep. Josip Bratulić, translated from Italian by Mate Maras, and Latin Darko Novaković. Split: Marjan tisak, 2004.

HACQUET, Balthasar: Oslikavanje i opisivanje jugozapadnih i istočnih Wenda, Ilira i Slavena. Split: Ethnographical Museum of Split, 2008.

HACQUET, Balthasar: Oslikavanje $i$ opisivanje jugozapadnih i istočnih Wenda, Ilira i Slavena. In: 
MØNNESLAND, Svein: Dalmacija očima stranaca, Dalmatia through foreign eyes. Ed. Tonko Maroević. Zagreb - Oslo: Fidipid - Sypress, 2011.

HALL, Stuart: Kome treba identitet? In: Politika teorije. Book of Proceedings from cultural studies.

Ed. Dean Duda. Translated by Sandra Veljković. Zagreb: Disput, 2006, 357-374.

LITHGOW, William in: MØNNESLAND, Svein: Dalmacija očima stranaca, Dalmatia through foreign eyes. Ed. Tonko Maroević. Zagreb - Oslo: Fidipid - Sypress, 2011.

MILIČIĆ, Irena: Teoretičari, hodočasnici, činovnici: tri vrste renesansnih putopisnih tekstova. Povijesni prilozi 38, 2010, 43-69.

MULVEY, Laura: Vizualno zadovoljstvo i narationi film (Visual and Other Pleasures, 1989, taken from iz Leitch, Vincent B. (gen. ed.): The Norton Antology of Theory and Criticism, English translation S. Merić. New York \& London, 2001, 2181-2192.

PAVLOVIĆ, Cvijeta: Alberto Fortis i hrvatska književnost. Umjetnost riječi, XLVIII, 1 (2004), 139-151. PEDERIN, Ivan: Putopisi prosvjetiteljstva. Radovi Filozofskog fakulteta in Zadar 38, 2002, 1-41.

PEDERIN, Ivan: Jadranska Hrvatska u austrijskim i njemačkim putopisima. Zagreb: Nakladni zavod Matice hrvatske, 1991.

PETROVIĆ, Danica: Pričevanja o putovanjih po balkanskem poluotoku od XV do XVII. stoletja: Glasbena folklora in ljudski običaji. In: Muzikološki zbornik - Musicological Annual 11, 1975, 5-16.

PIGAFETTA, Marco Antonio: Itinerario di Marc' Antonio Pigafetta gentil' huomo vicentino, Londra, apresso Wolfio Inghlese, 1585. In: MATKOVIĆ, Petar: Putopis Marka Antuna Pigafette u Carigrad od god. 1567. Starine, JAZU, 12 (1890), 70-194.

PYRCHMAIR, Hilarius: Comentariolus de arte apodemica, seu Vera Peregrinandi ratione. Ingolstadt, 1577.

QUICLET, Monsieur: Le voyage de M. Quiclet a Constantinople par terre: enrichis d'annotations, Chez Pierre Promé, 1664. (Fragment). In: MØNNESLAND, Svein: Dalmacija očima stranaca, Dalmatia through foreign eyes. Ed. Tonko Maroević. Zagreb - Oslo: Fidipid - Sypress, 2011.

SAPIEHA, Aleksander: Podróže w krajach stowiańskich odbywane. Wrocław, 1811.

SAPIEHA, Aleksander: Podróže w krajach stowiańskich odbywane. Wrocław, 1811. In: MØNNESLAND, Svein: Dalmacija očima stranaca, Dalmatia through foreign eyes. Ed. Tonko Maroević. Zagreb - Oslo: Fidipid - Sypress, 2011.

STAGL, Justin: A History of Curiosity: Theory of Travel 1550-1800. Salzburg, 1995.

VON GRÜNEMBERG: Konrad: Hodočasničko putovanje od Konstanza do Jeruzalema, 1486. Preveo Edo Pivčević, “Grünemberg o hrvatskim gradovima”. Hrvatska revija 2, Zagreb, 2005.

VON GRÜNEMBERG: Konrad Hodočasničko putovanje od Konstanza do Jeruzalema, 1486. In: MØNNESLAND, Svein: Dalmacija očima stranaca, Dalmatia through foreign eyes. Ed. Tonko Maroević. Zagreb - Oslo: Fidipid - Sypress, 2011.

VON RAUTER, Ludwig in: MØNNESLAND, Svein: Dalmacija očima stranaca, Dalmatia through foreign eyes. Ed. Tonko Maroević. Zagreb - Oslo: Fidipid - Sypress, 2011.

ROSTAGNO, Giovanni Batista in: MØNNESLAND, Svein: Dalmacija očima stranaca, Dalmatia through foreigne yes. Ed. Tonko Maroević. Zagreb - Oslo: Fidipid - Sypress, 2011.

VRANČIĆ, Antun: Putovanje iz Budima u Drinopolje. In: FORTIS, Alberto: Put po Dalmaciji. Prep. Josip Bratulić, translated from Latin by Darko Novaković. Split: Marjan tisak, 2004.

ZLATAR, Andrea: Povijest književnosti: kulturno pamćenje i interpretacija. In: BOGDAN, Tomislav et al. (eds.): Zbornik Dunje Fališevac. Zagreb: FF press, 2012, 489-496. 
ZLODI, Zdravka: Putopis Aleksandra Sapiehe u kontekstu epohe prosvjetiteljstva. Povijesni prilozi 32, 2007, 183-207.

prof. dr. sc. Divna Mrdeža-Antonina

Sveučilište u Zadru

Odsjek za kroatistiku i slavistiku

Obala kralja P. Krešimira IV 223000 Zadar, Chorvatsko

divna.antonina@gmail.com 